DOI 10.37882/2223-2982.2020.11.10

\title{
ПОРЯДОК КОМПЛЕКТОВАНИЯ ВОЙСК РОССИЙСКОЙ ИМПЕРИИ В СООТВЕТСТВИИ С УСТАВОМ О ВОИНСКОЙ ПОВИННОСТИ
}

\section{THE PROCEDURE FOR MANNING THE TROOPS OF THE RUSSIAN EMPIRE IN ACCORDANCE WITH THE CHARTER ON MILITARY SERVICE}

\section{A. Grischuk}

Summary: This article examined issues related to the procedure for manning the Russian army in the second half of the 19th century in accordance with the published Charter on military service. The features and order of conscription, service and terms, benefits are considered.

Keywords: charter, conscription, service, Russian Empire.
Грицук Анастасия Сергеевна

аспирант, Российский государственный социальный университет (РГСУ), г. Москва anastasia13571512@yandex.ru

Аннотация: В настоящей статье были рассмотрены вопросы, связанные с порядком комплектования русской армии во второй половине XIX века согласно вышедшему Уставу о воинской повинности. Рассмотрены особенности и порядок призыва, несения службы и сроки, льготы.

Ключевые слова: устав, воинская повинность, несение службы, Российская Империя.
B 1874 году был принят Устав о воинской службе. Документ включал в себя 224 статьи и 16 глав соответственно. И хотя он довольно небольшой по объему, все же в нем охватывается полный спектр всех необходимых воинских повинностей. Первая глава состоит из общих положений. В ней можно прочитать о том, что защита отечества - это священный долг каждого русского человека. Все мужчины должны были отбывать воинскую повинность в обязательном порядке. Стоит отметить, что данную статью ни разу за все время ее существования не пытались оспорить, что говорит о высоком чувстве ответственности перед своим отечеством у всех подданных.

Однако стоит заметить, что по поводу второй статьи, которая гласила о финансовом выкупе от повинности и том, что категорически нельзя заменять солдата охотником, стала причиной ряда дискуссий, хотя и подытоживала предыдущую статью. Больше всего противников данной статьи насчитывалось среди торговцев: категорически не согласны были представители Московского биржевого комитета, который передал Государственному Совету собственные решения. Торговцы уверяли, что они полностью разделяют мнение всех подданных касательно необходимости защиты отечества, но, несмотря на это, они просили о предоставлении возможности финансового выкупа и возможности замены охотников для старших сыновей тех, кто платит гильдию. Тут стоит заметить, что они уверяли - личные интересы для них не так важны, а их просьба обуславливается необходимостью поддержания торговых отношений и промышленности в стране. А при наличии такого выкупа у государства попрежнему оставались довольно существенные накопления, которые могли пойти на содержание опытных сол- дат в существующих войсках. Практически все участники комиссии не одобрили такую просьбу, поэтому выкуп и замену устав не дозволяет. Но все же есть определенное исключение, подтверждение которому можно найти в 51-й статье, которое дает возможность проводить замену в пределах одной конкретной семьи: например, если человек проходил на данный момент армейскую службу или призывался для ее прохождения, за него мог пойти сводный, родной или двоюродный брат по собственному желанию, если только он сам не входил в число призывников и не числился в рядах запаса. Возраст такого человека должен был составлять 20-26 лет. Он должен отслужить вместо родственника в основных рядах и в запасе весь положенный срок, а юноша, которого он заменяет, будет служить в рядах ратников [1].

Также стоит сказать, что положения в рассматриваемом нами уставе определяли состав военных сил: в них входила основная армия и ратники (ополченцы), которые вступали в бой только в чрезвычайных ситуациях. Постоянная армия включала: а) общую, набор в которую проходил каждый год; б) резерв, в состав которого входили люди после того, как отслужили основной срок; в) казаков; г) ряды инородцев. Что касается общего состава ВC, то и по этому поводу возникали серьезные споры, поскольку многие хотели расширить указанный выше список. Например, было предложение создать еще один резерв, состоящий из рекрутов, но оно было отвергнуто. Призывы на службу проводились по воле жребия, который тянулся только раз и определял дальнейшую жизнь мужчины - в зависимости от того, какой жребий был вытянут, человек определялся в постоянные войска или в ряды ополченцев [2]. Каждый год возраст тех, кто тянул жребий, оставался прежним - только юноши, которым 
по состоянию на 1 января того года, в который проводился призыв, уже исполнилось полных двадцать лет, могли тянуть этот жребий. И этот вопрос тоже вызвал ряд споров, поскольку было немало прений насчет того, действительно ли нужно проводить каждый год призывы юношей строго указанного возраста, или можно расширить этот показатель, как было раньше, во время проведения набора рекрутов на службу. Раньше служба в рядах армии считалась тяжелым наказанием для преступников, но затем ее статус резко изменился - теперь отбывать службу были обязаны представители всех сословий. Не служить могли только оговоренные по суду лица [3].

Призыв проводился каждый год по всей европейской части России в период с 1 ноября и по 15 декабря. С начала следующего года бойцы обучались военному ремеслу, и к тому времени, когда объявляли о прохождении сборов, они уже могли стать в основные войска. Обычно весной начинались войны и военные конфликты, поэтому новобранцы играли в этом важную роль. Когда наступал срок возвращения из лагерных сборов, солдаты «старой» службы, как правило, увольнялись, а значит, на протяжении осеннего времени российские войска значительно ослабевали. Хорошим моментом стал тот факт, что именно осеннее время считалось периодом затишья между военными действиями. В процессе определения подходящего периода призыва обязательно учитывалось, чтобы ранний набор не стал преградой к проведению осенних полевых работ.

Еще одним спорным моментом оказался вопрос, который касался длительности службы в армии. Небольшие сроки были одобрены, поскольку именно в таком случае основная часть солдат может пройти армию, а каждый конкретный солдат ненадолго отрывался от своих рядов.

Примечательным фактом является увеличение количества людей, которые каждый год отрывались от привычной деятельности, но при этом стоит отметить, что далеко не все они потом к ней возвращались. Тратилось очень много сил, времени и денег на передвижение людей домой, и на передвижение тех, кто собирается пополнить ряды армии.

Перечисленные выше факторы стали основной причиной, по которой даже те люди, которые изначально выступали за сокращение сроков службы, проголосовали за отбывание ее в течение 5-ти лет, а не 4-х, как это планировалось ранее. Но при этом стоит отметить, что это очень важный вопрос, ведь в воинской повинности не осталось бы никакого смысла, если бы в составе армии числились не опытные бойцы, а обычные юноши и мужчины, которые не знакомы с ратным делом. Именно по этой причине эксперты по военному делу решили продлить срок службы в армии до 6 лет, обозначив этот срок минимальным, который требуется для обучения военному ремеслу.

Также следует отдельно отметить, что срок службы в рядах сухопутных войск для тех, кто поступал туда согласно вытянутому жребию, составлял целых 15 лет, из которых в течение шести лет солдаты служили в основном составе, после чего находились в резерве в течение дальнейших девяти лет. Но и здесь действуют определенные исключения для тех, кто входил в состав армии Туркестанского округа. Кроме того, были и другие исключения: например, для солдат, которые отбывали службу в Семиреченской, Приморской или Якутской областях. В данном случае солдаты служили в течение 13 лет, из них семь лет уходило на основную службу, а остальные шесть лет проводились в резерве [3].

Учитывая значительные расстояния, которые отделяли место расположения войск от тех мест, в которых производился набор новых солдат, новые бойцы больше бы передвигались к месту назначения, чем действительно служили. Кроме того, в случае решения существенно сократить сроки отбывания службы приходилось бы постоянно отправлять в одну и другую сторону гораздо больше людей. А это точно не способствовало бы экономии государственных средств, кроме того, сами переходы были достаточно тяжелым мероприятием. Вопрос был решен так: после того, как отбывался срок основной службы, человек переводился в резервные войска, что считалось наградой за честно отслуженные годы. Конечно, при этом следует заметить, что сокращение длительности пребывания солдат в таком резерве снижает их численность, но все равно это не отражается негативным образом на общей военной способности государства, поскольку войска даже в отсутствие военных действий находятся в полном своем составе.

На флоте бойцы служили в течение десяти лет, из которых семь уходило непосредственно на службу, а остальные три отводились для пребывания в резерве. Стоит отметить, что все сроки, которые упоминались тут и ранее, относятся только для мирного времени. Если наступает военное время, то все, кто на данный момент находится на службе, должны нести ее до тех пор, пока в этом будет необходимость [4].

Помимо прочего, стоит сказать, что морское и военное министерства могли отправлять в состав резерва солдат в процессе отбывания ими службы в отпуск сроком до года.

Если говорить о тех, кто служил в резерве, то их могли призвать на основную службу только в крайних случаях и только в соответствии с Указами, которые издавались правительством. При этом бойцы, которые служили 
в запасе, не освобождались от учебных сборов и должны были присутствовать на них, но действовали соответствующие ограничения: не чаще 2-х раз на протяжении всего периода отбывания службы в резерве, а каждый отдельный раз не должен превышать длительности в 1,5 месяца [5].

Не все призывались из запаса на основную службу. Чиновники, которые занимали высокие государственные или социальные должности, отделялись в определенный перечень, который относился на Высочайшее утверждение в комитет министров. Также стоит отметить, что в ряды ополченцев входили люди, которые вытянули соответствующий жребий и не могли служить в постоянных войсках, а также те, которые уже отслужили свой срок в резерве и в основных рядах.

Несмотря на то, что общую воинскую повинность, согласно изданному Уставу, должны были отбывать все, полностью соответствовать этому правилу просто невозможно на практике. Если исключить из числа юношей-подростков тех, кто имел инвалидность или по состоянию здоровья не способен служить, количество тех, кто останется, все же будет больше, чем количество людей, набираемых каждый год на службу. Учитывая срок отбывания службы, который обозначен шестью годами, армия просто не сможет вместить в свои ряды всех призывников, и это становится основной причиной, по которой было решено тянуть жребий. Это считалось своеобразной волей случая - кому поступать в основные войска, а кому - в ополчение, но тут стоит заметить, что даже в таком случае действовали определенные льготы для некоторых категорий лиц. Такие льготы существуют во всех государствах, но сказать что-либо конкретнее сложно, ведь в каждом государстве они определяются индивидуально исходя из определенных потребностей. Важно только, чтобы все льготы распределялись справедливо.

Все подобные льготы собраны в шестой главе Устава и поделены на такие категории:

1. отсрочка по состоянию здоровья;

2. по положению в семье;

3. по положению имущественного характера;

4. образованию;

5. по виду деятельности.

После прохождения всех необходимых сроков воинской службы люди, которые свободно выбирали ее направление, могли переходить в запас на срок 9 лет или продолжать служить в основных рядах. Но во времена военных конфликтов они должны находиться на действительной службе до того момента, пока в них будет потребность [6].

Именно такие сроки были приняты упомянутым выше Уставом для тех юношей, которые получали соответствующее образование. Но даже те, которые прошли службу в течение 12 недель или полугода, недостаточно опытны для ведения военного дела. Но тут же стоит сразу сказать, что на западе таких коротких сроков отбывания службы не наблюдалось. Причина их наличия кроется в том, что совсем немногие оканчивали высшие заведения в то время в России. Согласно официальным данным, их количество не превышало 900 человек за год. Из них половина подлежала освобождению от прохождения службы в мирное время в связи с особенностью своей деятельности. Они проходили службу в резерве. К такой категории людей относились медицинские работники, филологи и математики, которые преподавали свои дисциплины в соответствующих государственных учебных учреждениях. Учитывая все вышесказанное, вторая половина выпускников, которых была примерно 500 человек, должна была проходить полную воинскую службу. Но тут же стоит сказать, что не все из них поступали в войска, поскольку многие оказывались увечными или имели льготы по семейному положению. Можно примерно предположить, что в результате из общей массы, которая изначально составляла около 900 человек, останется только 250-300, которые могли отбывать воинскую повинность. Это слишком маленькое число, поэтому решение увеличить срок службы для тех, кто окончил образование, не принесет никакой пользы для общего военного дела России, государства и самих служащих [7].

Теперь рассмотрим вторую группу людей, которые могут отбывать сокращенную службу по образованию. К ним относятся ученики, которые прошли обучение шести классов гимназии, семинарии или соответствующих учреждений. Выпускников таких учреждений в общей сложности насчитывалось примерно 1580 человек каждый год. Из них около 0,9 продолжали путь образования в университетах. Остается примерно 160 юношей, которые пригодны для прохождения воинской службы. Именно поэтому для них нет значительных льгот, ведь их количество тоже очень незначительно. Учеников, выпустившихся из гимназии, каждый год насчитывалось примерно три тысячи человек. Учитывая тот факт, что 50 \% из них оказывались льготниками по тем или иным критериям, остальные 50 \% были пригодны для отбывания повинности. Но даже такого количества недостаточно для того, чтобы пополнить количество офицеров армии, убывающих с каждым годом после окончания службы.

При этом следует отметить, что некоторые из перечисленных юношей будут тянуть жребий, который освободит их от повинности, а многие, отслужив положенное время, пойдут работать в гражданскую сферу, чтобы занять высокие должности и не подлежать мобилизации даже в случае наступления войны. И только небольшое количество из всех вышеперечисленных становились офицерами или оставались в рядах армии. Сразу заме- 
тим, что армия очень нуждалась в грамотных офицерах, в результате чего пришлось на последующий разряд учебных учреждений смотреть не только как на тот, что предоставляет льготы, но и как на тот, который является основным и единственным источником восполнения офицеров в армии. Даже до того момента, как был издан упомянутый в работе Устав, офицерский состав пополняли выпускники образовательных учреждений, относящихся к третьей категории, поскольку основной их частью - примерно 80 процентов - являлись представители дворянства. Кроме того, что сроки службы сокращались, важно было также обеспечить поступление на службу таких людей, но при этом за ними сохранялось право самостоятельно выбирать направление службы.

Действие всех вышеперечисленных льготных усло- вий оказало весьма положительный эффект. До момента их внедрения армия России отличалась недостаточным количеством офицеров, а после того, как в 1874 году был принят Устав, эта проблема решилась достаточно быстро. Стоит сказать, что упомянутый нами документ не полностью достиг поставленной цели, поскольку не предоставлял необходимых условий для развития офицерского резерва. Кроме того, солдаты, получившие высшее или среднее образование, служили непродолжительное время и просто не успевали стать офицерами.

Именно по этой причине в Уставе, который был принят в 1886 году, был увеличен срок прохождения службы для выпускников высших и средних учебных учреждений, а также были установлены дополнительные льготы для получения офицерского звания.

\section{ЛИТЕРАТУРА}

1. Высочайше утвержденное мнение Государственного совета «0б увеличении сроков действительной службы для лиц, получивших высшее и среднее образование, и о вызываемых сею мерою изменениях в Уставе о воинской повинности», Полное Собрание Законов Российской Империи. Собрание третье. СПб., 1888. T. VI. 1886. № 3508.

2. Закон «0б изменении Устава о воинской повинности», Полное Собрание Законов Российской Империи. Собрание третье. СПб. 1915. Т. XXXII. 1912. Отделение І.№ 37417.

3. Сборник законоположений по отбыванию воинской повинности вольноопределяющимися и охотниками /Сост. М.В. Андрушкевич. Кутаис: Тип.-лит. М.И. Гамрекели, 1899.

4. Устав о воинской повинности. Спб.1874; ПСЗРИ. Собрание 2-е. Т.49.0гд.1. № 52983. Ст.17.

5. Устав о воинской повинности. Спб.1874; ПСЗРИ. Собрание 2-е. Т.49.0гд.1. № 52983. Ст.20.

6. Устав о воинской повинности. Спб.1874; ПСЗРИ. Собрание 2-е. Т.49.0гд.1. № 52983. Ст.23.

7. Устав о воинской повинности. Спб.1874; ПСЗРИ. Собрание 2-е. Т.49.0гд.1. № 52983. Ст. 156.

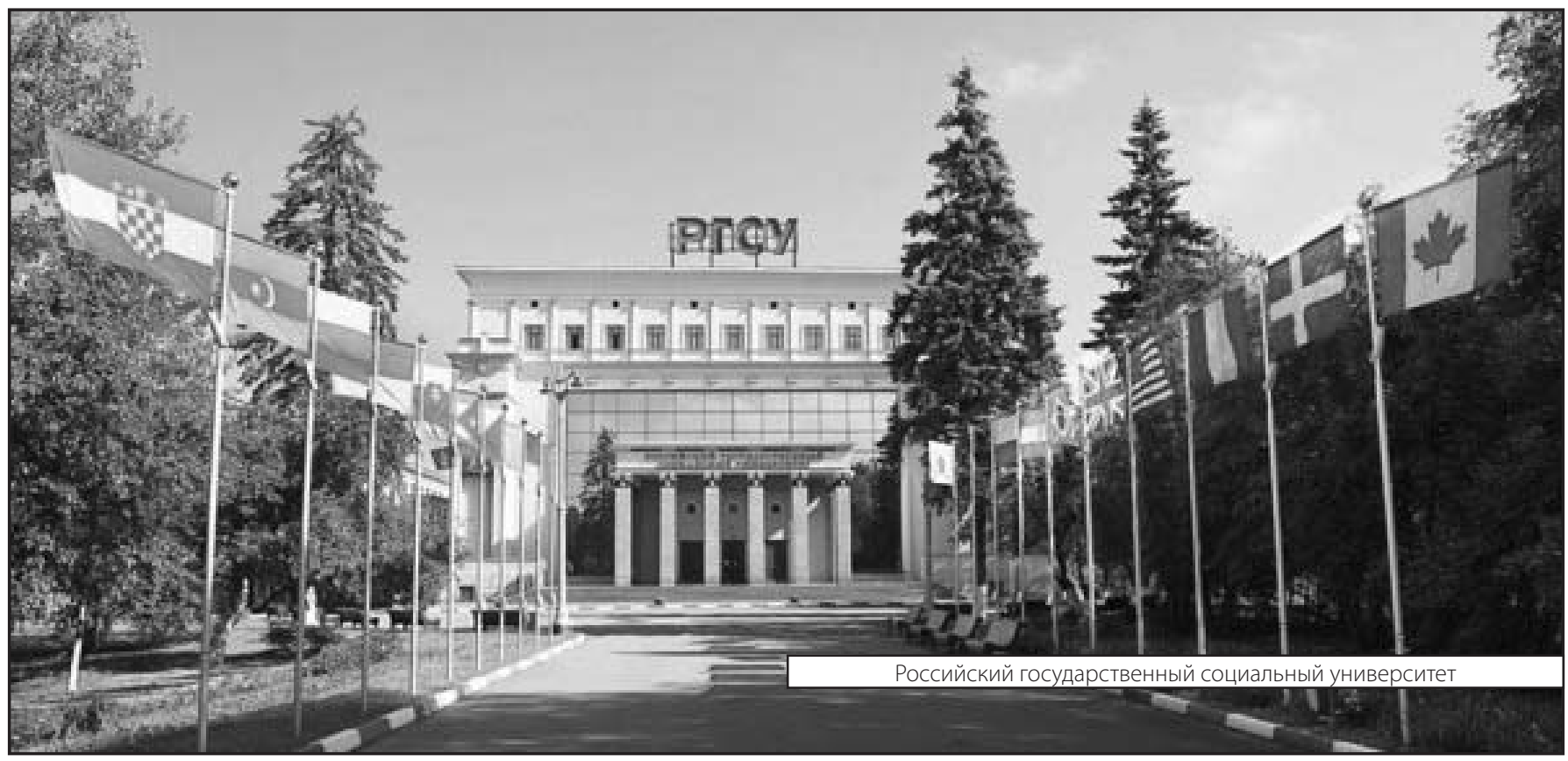

